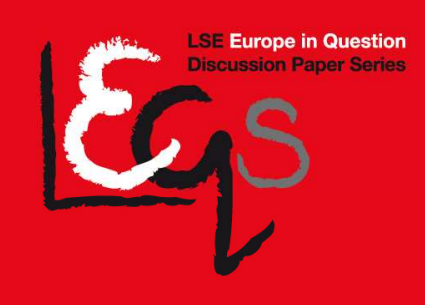

LSE 'Europe in Question’ Discussion Paper Series

\title{
The European Heritage from a Critical
}

\section{Cosmopolitan Perspective}

\section{Gerard Delanty}

LEQS Paper No. 19/2010

February 2010

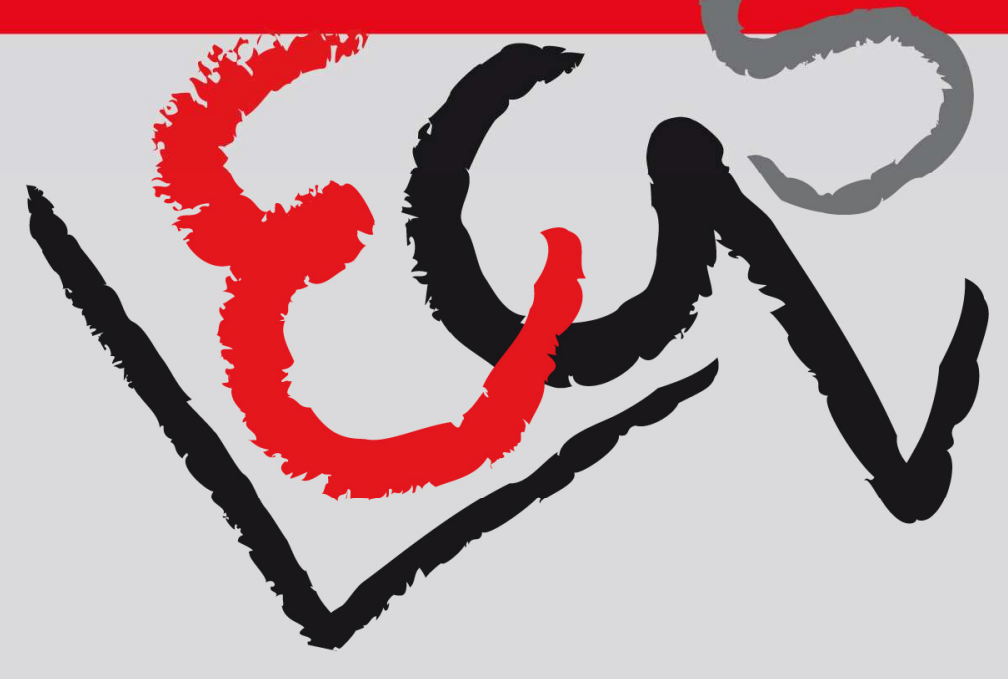




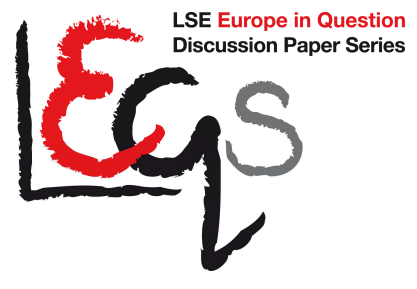

\section{Editorial Board}

Dr. Joan Costa-i-Font

Dr. Vassilis Monastiriotis

Dr. Jonathan White

Ms. Katjana Gattermann

All views expressed in this paper are those of the author and do not necessarily represent the views of the editors or the LSE.

(C) Gerard Delanty 


\title{
The European Heritage from a
}

\section{Critical Cosmopolitan Perspective}

\author{
Gerard Delanty*
}

\begin{abstract}
The question of the European cultural heritage and the wider historical legacy of Europe has been the subject of much discussion in recent years as is reflected in new approaches to memory and commemoration, values, and European identity. Unlike earlier histories, which generally contained a 'grand narrative,' new histories of Europe are now generally more cautious in their assumptions about a continuity or a narrative based on the advancement of civilization. The general trend is towards a greater recognition of rupture, which must be measured against continuity, a unity in diversity and a certain problematization of the received values of tradition. This paper looks at various models for theorizing the European heritage in the wake of the end of the Grand Narrative accounts and makes the case for a critical cosmopolitan approach.
\end{abstract}

\footnotetext{
* University of Sussex

Professor of Sociology and Social \& Political Thought, Department of Sociology, University of Sussex, Brighton, BN1 9SN, UK

Email: g.delanty@sussex.ac.uk
} 


\title{
Table of Contents
}

\author{
Abstract
}

1. Introduction 1

2. Cultural Heritage and the Problem of Culture 4

3. The Decline of the Grand Narratives 6

4. Beyond the Grand Narratives: the pluralisation of the $\begin{array}{ll}\text { European Heritage } & 10\end{array}$

$\begin{array}{ll}\text { 5. Conclusion } & 18\end{array}$

References 


\section{The European Heritage from a}

\section{Critical Cosmopolitan Perspective}

\section{Introduction}

The year 1989 marked a significant turning point in European history for many reasons. Politically it marked the end of major ideological divides within Europe and opened the way for a new phase in the European project. As is now only too apparent, the open horizon of the future that seemed to have been signalled by 1989 considerably faded by the early 1990s when the European past reasserted itself in the form of numerous nationalist conflicts. Prior to 1989 it was possible to speak of European unity only at the cost of excluding central and eastern Europe. The unity of Europe was the unity of the West and a unity that could with some plausibility be described as a political project underpinned by certain assumptions, such as liberal democracy, capitalism and Christianity. While 1989 opened up new opportunities for the project of European integration, leading to the enlargement process and the movement towards a quasi-constitutional structure, it has paradoxically led to greater uncertainty as to the identity of Europe and its values. It is not an exaggeration to speak of a crisis of European identity since about 1991. In this paper I would like to examine this crisis with respect to the question of how we should understand the European heritage today in light of the issues opened up by 1989. My question is whether it is possible or meaningful to speak of a common European tradition or heritage. In what sense should we understand the idea of 'unity' or commonality today? Is it meaningful to speak of common values in postmodern times (see Joas and Wiegandt 2007)?

It would be tempting to conclude that a large-scale multi-national entity such as the EU cannot be based on a shared value system, but I shall argue that despite the apparent obstacles it is possible to conceptualize commonality in ways that are 
appropriate to the present day. Before looking at this I would like to address two refutations of the possibility of a European identity that one often hears and which derive from two quite different positions. The first is the thesis that a European political identity either does not exist or can be only a weak identity in contrast to national identities. The second is the view, often associated with postcolonialism, that philosophically the European heritage is necessarily Eurocentric and inseparable from colonialism or is beset by internal divisions to a point that no unity is possible or even desirable.

Regarding the first argument, the current situation is less one of the absence of a political identity than one of competing visions of the future of the project of European integration. This element of competition is more important than is immediately apparent since it does not mean the impossibility of identity or community. Such competition can be seen as productive of new realities which are generated in contexts of debate. The dominant force is undoubtedly the idea of a democratic Europe based on the sovereign national constitutional state, with the EU as a regulatory regime concerned largely with economic pursuits around market regulation. Against this largely intergovernmental vision of Europe rooted in notions of sovereignty and national autonomy, there are various postnational visions that stand for a post-sovereign Europe in which the nation-state has reduced significance. For the moment it would appear that the latter trend has been weakened, due both to the consequences of the enlargement of the EU and the global financial crisis, which has revealed a limited capacity of the EU to act as an integrated body. However, whatever shape the EU will take in the future, it will not entirely escape from the post-sovereign course it has embarked on and its political identity will doubtlessly be contested. But, then, too most expressions of national identity are also contested. The point I wish to make is that the absence of a straightforward European political identity does not foreclose the possibility of a European political community based on values other than economic ones. The fact that these values may be contested does not mean the in principle absence of community or warrant the conclusion that it can only be a 'thin' kind of commonality in contrast to an allegedly 'thick' national identity. Collective identities of all kinds are variously both thin and thick and 
increasingly take more discursive forms than they did in the past and are open to more and more interpretations. Indeed, it has often been noted that people's identity is often too ambivalent to amount to a coherent fully formed collective identity. This lack of coherence is particularly apparent when it comes to considerations of Europe and the question of a European postnational identity. So my first preliminary point is that the absence of a coherent political identity does not signal the impossibility of political community.

A second argument I mentioned is addressed to a wider conception of Europe beyond the political. An objection frequently made against the notion of a European identity, or the viability of an alternative reading of the European heritage, is that the very idea of the European past is inseparable from Europe's legacy of colonialism. The main consideration I wish to highlight in this context is that this position does not address what I think is an essential precondition for any debate on the European heritage, namely the recognition of the critical and post-universalistic strand within European culture over the past two hundred years. An interpretation of the European heritage that takes this into account is what is needed, as I shall argue later. The point I wish to make is that one core tradition within the European heritage is the interrogation of the past and the genesis of a post-traditional conception of culture. This can be associated with the notion of modernity understood as a site of conflicting interpretations of the world rather than a legislating authority. Post-universalistic conceptions of truth and identity have been widely recognised in almost every aspect of late twentieth-century thought. The various philosophies of Deleuze, Derrida and Foucault all argued for the absence of a constitutive subject and oppose representational conceptions of culture with more transformative ones (see Derrida 1994). History contains no inherent pattern of meaning and cannot be viewed in holistic terms as constitutive of an overall unity or the expression of a subject. Habermas, too, has argued for a conception of culture based on collective learning processes in which communicative modes of reason gain increased salience. The importance of these ideas for theorizing the European heritage should not be underestimated. What they point to is an anti-essentialistic view of culture that has lost its capacity to legitimate and which exists only as a 
mode of communication in which the past is interrogated. In short, what is required is a theory of cultural heritage that is sensitive to dialogic concepts of rationality, selfproblematization and critique. What notion of culture does this imply?

\section{Cultural Heritage and the Problem of Culture}

To discuss culture - in the sense of cultural identity or heritage or European or national values or ethnicity - unavoidably requires recourse to something that binds people or some sense of a shared form of life and also requires recognition of the fact that all of culture is today fragmented, fluid and there is no form of life that is not contested and divisive. Rather than choose one of these options or abandon the notion of culture altogether it makes more sense to find a more general definition of culture that makes possible an accommodation of these divergent approaches. Many of the problems reside in the problem of relating culture to a particular subject. The question of a European cultural heritage needs to be posed in a way that does not reduce heritage to a specific subject to which a particular form of life can be related. Rather what is more pertinent is to specify the ways by which European societies interpret their themselves and their collective goals and aspirations. This is best termed a cultural model, which includes normative content and imaginary significations.

The notion of a cultural model, introduced by Alain Touraine (1977), refers to a society's capacity for self-interpretation. As used here it is also influenced by Habermas's notion of culture as a domain of critique and reflection and Castoriadis's notion of imaginary significations. ${ }^{1}$ The cultural model of society includes its normative orientations and self-understanding. It is not reducible to a cultural or political identity or a collective identity, since it does not relate directly to a specific collectivity and nor is it an objective cultural system of meaning or value framework. The cultural model of society is a more general level of cognition, reflection,

\footnotetext{
${ }^{1}$ Strydom (2006) stresses the cognitive component of culture. The notion of a cultural model entails a cognitive conception of culture.
} 
creativity (Touraine speaks of an 'image of creativity' that allows a society to give political direction). The concept of a cultural model has the advantage of solving a basic problem in the concept of culture, namely a view of cultural as a whole way of life and culture as divided and contested.

The notion of a cultural model has particular relevance to something as broad as Europe, though arguably the same applies to the analysis of a national society given the highly differentiated and diverse nature of all societies today. The notion of a cultural model offers a way to conceive of public culture as non-essentialistic. Notions of culture as either 'thick' or 'thin' frequently lurk in the background of many approaches to post-national culture, which is generally regarded as a thin version of national culture. The argument put forward in this paper is that we need to avoid the dualism of thin versus thick conceptions of culture and also the notion that political identity must be underpinned by a cultural identity understood as a whole form of life. My argument then is that the notion of a European cultural heritage should be best seen in terms of a cultural model by which societies interpret themselves. Viewed in these terms we can reconcile the contested conception of culture with a more general view in that a cultural model can constitute itself a site of conflicting interpretations of the world but in which there are possibilities for acts of signification. This essentially communicative concept of culture also opens up the cosmopolitan possibility for a reflexive relation between cultures (see below).

If this is to be called identity (and it is best that it is not) it should be distinguished from personal identities and from collective identities, both of which presuppose a subject, whether an individual person or a particular form of life associated with defined group. To speak of European identity, in the sense of the identity of Europe, is meaningful only if is clear that by European identity is meant something more than collective identity (Eder 2009). Group based identities - whether national identities or ethnic identities - generally do not produce societal cultural models and have a declining capacity to do so. Indeed, as has been often noted in sociological research on identity, people's consciousness and identity is generally too ambivalent to amount to a coherent fully formed collective identity. Where this might be 
possible, as in for example nationalism or organized political movements, the collective identity in question gains it shape from processes of mobilization and is not in a straightforward sense the result of prior or antecedent identities. It has been widely noted that collective identities are constructed through mobilization (Melucci 1996). This perspective generally lends itself to a constructivist approach to collective identity formation. This is true of national identity as it is of any kind of collective identity. With respect to the question of European identity, we need to distinguish between the political identity of the European Union, the degree to which people identify with it and whether or not they have a European identity. ${ }^{2}$ Such considerations will need to take account of the fact that most people have multiple identities and these are frequently overlapping (this is not necessarily the case for institutions or collective actors). All of these questions are quite different from the question of a European identity in the sense of a European cultural model or a European heritage, for this will entail going beyond how people identify with the European Union.

\section{The Decline of the Grand Narratives}

It has been undeniably the case that the very idea of a European heritage has been bound up with what may be called grand narratives, the idea of a cultural tradition that transcends the divisions and plurality of Europe and has provided a connecting tread in European history. Such ideas were common place since the Enlightenment and while such ideas were often contested and were frequently in conflict with national grand narratives and other more cosmopolitan ones, they were influential in shaping the cultural and political identity of the EU in its formative period. These ideas have lost their credibility today, but for much of the twentieth century they provided a kind of background legitimation for the European project, including earlier forms of internationalism. It was often the case that a notion of civilization

2 On European identity see Antonsich (2009), Checkel and Katzenstein (2009), Delanty and Rumford (2005), Eder (2009), Kantner (2006), Sassatelli (2009). 
was at stake in such notions of the European heritage whereby civilization transcended the diversity of cultures. The 1973 Copenhagen Declaration of European Identity is one such example of a simplistic appeal to a singular notion of Civilization based on common values that have somehow survived the divisions of history. It referred to a 'common European civilization' based on a 'common heritage' and 'converging ways of life': 'The diversity of cultures within the framework of common European civilization, the attachment to common values and principles, the increasing convergence of attitudes of life, the awareness of having specific interests in common and the determination to take part in the construction of a united Europe, all give the European identity its originality and its own dynamism.'

The influential Euro-federalist school of historiography, as associated with historians such as Duroselle (1990) and Brugmans (1966, 1987), generally invokes a common European identity that has progressively unfolded in history and reveals a unity of purpose that finally takes a political form with the foundation of the EU. Such grand narratives were often attempts to counter rival accounts. Thus Karl Jaspers (19470 argued for a vision of the European heritage in terms of a notion of freedom and which was conceived in opposition to the pessimistic Spengelerian theory of the decline of the West and notions of European decadence. Other forward looking grand narratives include the writings of Denis de Rougemont $(1965,1966)$, who attempted to articulate a notion of a common European identity that was intended to be an alternative to purely market notions of European integration. The period from c 1914 or so to 1989 was a period in which such grand narratives were the most common ways in which the European heritage was conceived. This was a period in which general visions of political order were common place, as in programmatic ideologies for social and political reconstruction such as imperialism, socialism, communism, national socialism, and more generally nationalism. The grand narratives associated with the European heritage were largely modest, if not naive attempts to provide alternative approaches to history and politics.

It is easy to be dismissive of such grandiose concepts of heritage, especially today in light of more critical approaches to culture and post-Foucauldian approaches to 
history that stress rupture over continuity, but to conclude that if there is no grand narrative there can be no meaningful sense of a European heritage is, I argue, unwarranted and something like a post-universalistic and post-western conception of the European heritage is possible. In recent years there has been considerable questioning of some assumptions that lay behind the grand narratives. The idea of Western Civilization as a singular and universalistic condition with a capital ' $\mathrm{C}$ ' has been mostly refuted. Such developments have been linked to reconsiderations of the ontological assumptions of the values on which civilizations are supposed to be based. It is becoming increasingly difficult to see these values as primordial or as given. The political Left since the 1980s has attacked the very idea of civilization, which has generally been seen as a legitimation of colonialism. Postmodernism, which emerged out of this Left discourse, and post-colonial thought declared not only the obsolescence of modernity but also the civilization that modernity was based on. The idea of a 'western canon', based on the core texts of 'Western Civilization' came increasingly under fire since the late 1970s. As a result of the discrediting of a universalistic idea European civilization, the idea of culture moved into the fore and with this has came a concern with identity. These shifts have also opened up a space for a reinterpretation of the notion of civilization beyond the grand narratives of the rise of the West as well as beyond simple claims to identity.

Civilizations are important vehicles through which historical memory is transmitted. European memory and the meaning of Europe is, in part, shaped by civilization. But what that civilization consists of is not self-evident. Many conceptions of European civilization are highly contestable, due to the assumptions they make about the nature of civilization, and often have political implications. But, I argue, it is possible to understand European civilization in a way that is relevant for the present day. Europe cannot be defined in narrow political terms as a set of core western nationstates based on the Carolingian Empire of the early Middle Ages and in cultural terms as a culture based on the values of the Renaissance and Enlightenment and modern democracy. Such definitions are often exercises in the political instrumentalization of history and culture. Europe can also be interpreted as being based on a wider and more cosmopolitan sense of civilization as post-universal and 
entailing a dialogue of cultures. As Brague (2002) and others have argued, the European self, the subjectivity of modern Europe, has been variously defined by reference both to an Other - the non-European - and to its own self - classical culture - which was experienced as distant and often irrecoverable.

Following the approach of the Jürgen Habermas it is possible to see history as a learning process. Societies learn in ways different from the ways individuals learn, but it is possible to speak of such collective learning processes. Viewed in terms of a developmental learning process, civilization can be seen as a continuous re-working of the legacies of the past. The capacity to learn from history was, Habermas has argued, particularly characteristic of modernity which led a condition in which power - both state power but also class power - was constantly challenged by social movements and civil society. The great social movements of the modern age - the workers movement, the anti-slavery movement, anti-colonial movements, feminism, and the ecological movement - have been among the most important carriers of collective learning.

Without the capacity to learn from history the present will be condemned to repeat the errors of the past. While there is much evidence of such failures to learn from history, there are also examples of how societies have learnt from history. Certain aspects of the European civilizational heritage such as the constitutional and democratic state, human rights and the integrity of the human person, social solidarities, civil society and the critical reason associated with modern thought represent a legacy that is of continued importance for the present. These are products of the European political and cultural heritage and have become of universal significance in what is now a globally connected world, albeit one in which Europe is only a small part. Although these are values that are no longer specifically European, they have had their origin in the great social struggles and movements in the European past. As a learning process, then, history also contains the possibility for societies to transcend the given and inherited. In the present day such considerations are of the utmost importance as the European Union has for the first time established a political framework that embraces much of the European continent. 


\section{Beyond the Grand Narratives: the pluralisation of the European Heritage}

In this paper I argue that the question of the European heritage should be seen in terms of not one grand narrative, but rather in terms of several competing ones. In short, we are in the age of the break-up of grand narratives. However the idea of a European heritage should still be seen as a narrative, but of a different kind. Narratives offer new interpretations of the present; they are ways of experiencing and interpreting time and situate the present in relation to the past and future (see Eder 2009). Unlike earlier histories, which generally contained a 'grand narrative,' new histories of Europe are entirely devoid of any attempt to discern a meaningful pattern. Norman Davies (1996) in his history of Europe does not tell the story of Europe in terms of anything that could be the basis of a self-understanding for the present. G. A. Pocock has denied the existence of such thing as European history, claiming that there are only different constructions of Europe which means many different things to many different people (Pocock, 1997, 2002) and in his survey of post-war Europe, Tony Judt (2005) also avoided any single conclusion. In my view, this is not entirely helpful, since we end up, on the one side, with the view that there is a persistence of history and on the other side that there is nothing in European history to offer the present.

While historians have been reluctant to offer an interpretation of the European heritage, the perspective of historical sociology is rather more interesting. Johann Arnason $(2003,2006)$ has argued that there were many reasons why Europe diverged from other Eurasian regions but the overall dynamics of the process can only be understood in a global context of intercivilizational encounters, for Europe's rise and modernity was due in part to its interaction with other parts of the world and in part due its own internal advantages. In this view, against the dichotomy of internalist or externalist accounts, the 'rise of the West' is best understood as an interactive process. The implications of Arnason's proposals for an understanding of the European heritage suggest that neither the traditional view of the uniqueness of 
Europe nor the orientalist critique offer a satisfactory account of European history. It is possible to see four main narratives of the European heritage at work today: heritage as a shared political tradition, heritage as a unity in diversity, heritage as trauma, and a cosmopolitan heritage.

\section{Heritage as a Shared Political Tradition}

The first and most obvious way to define the European heritage is to relate it to a political tradition as opposed to a wider cultural characteristic. Against for instance, a definition of Europe as Christian or a definition that posits a universalistic value such as freedom, a narrower political conception of the specificity of Europe offers an alternative to the grand narratives that posit the progressive unfolding of an idea becoming embodied in a political form. In this regard, one can find within European history a value orientation that might be the defining characteristic of its political heritage for the present day. Whatever this will be will partly depend on what might be taken as the most important development or direction Europe is undergoing. If we take the trend towards a post-sovereign order, on the one side, and on the other the contemporary concern with democracy and citizenship, we get quite different understandings of history. Thus, the post-sovereign trend will highlight alternatives to the state tradition, while a concern with democracy and citizenship will draw attention to civil society.

To take the latter case of the centrality of democracy and citizenship, it has been argued that the political tradition that most captures the European heritage is republicanism (Van Gelderen and Skinner, 2002). The republican tradition, or to be more specific the civic republican tradition, with its concern with civil society and the notion of a self-governing political community based on autonomous individuals is indeed a distinctive feature of the European political tradition. While it can plausibly be argued that it offers a shared heritage for much of Europe, it is possibly not as widely shared as is often assumed. For instance, its applicability to central and eastern Europe is not evident and it has not always led to democracy, as is illustrated 
by the example of seventeenth-century English republicanism. It is not also not evident why republicanism is more central than for instance liberalism, which has arguably provided the foundations for European democracy and the modern state. The most plausible case can be made for a conception of the European heritage based on republicanism is the Kantian vision of a Europe based on a narrative of peace and constitutionalism. This vision, which has been invoked by Habermas (2001), extends the republican idea from the national level to the wider international context in a way that has some resonances in the current trend towards a post-sovereign European political order. However, this interpretation does not go unchallenged, since an alternative reading of European political liberalism will posit less the transformation of the state than individual rights as the salient factor.

The problem, in essence, is that the European political heritage does not consist of just one tradition, but several. The tension between liberalism and republicanism between an emphasis on individual rights and on a self-governing political community - is one illustration of this wider tension within democracy. But more than this, it can also be argued that the defining feature of the European political heritage is not liberty or democracy as such, but the concern with social justice. Certainly when one looks at Europe from a global perspective, it is the struggle for social justice that stands out as the most prominent feature of Europe's political heritage and a key characteristic of the formation of modernity. Modernity evolved in Europe, unlike in other parts of the world, in a way that capitalism and state formation were constrained by the taming influences of civil society, including social movements concerned with social justice. The result of the interaction of state, capitalism and civil society in modern Europe was the triumph of social justice. However, rather than conclude that democratic socialism was more important than liberalism or republicanism, one should rather draw the conclusion that the European political tradition did not lead to one overall outcome. Instead, what is more important is a plurality of political traditions leading to a plurality of interpretations of heritage (see Wagner 2009). 


\section{Heritage as a Unity in Diversity}

The search for a political tradition that guarantees the specificity of the European political heritage as a shared tradition runs into the problem of multiple political traditions. An alternative narrative that has considerable relevance today is the idea of unity in diversity. In this perspective, a narrative of becoming overshadows the idea of a past shared. Europe is not yet a unity, but out of its diversity a political unity based on national cooperation and understanding is possible.

In this narrative European history has been one in which difference has been a factor that cannot be ignored or regarded as an inconvenient obstacle to unity. The idea of unity in diversity has increasingly come to the fore in European cultural policy, which shifted the earlier emphasis on unity to one of regional diversity (Sassatelli 2009). As stated in the Maastricht Treaty in 1992: 'The Community shall contribute to the flowering of the cultures of the Member States, while respecting their national and regional diversity and at the same time bringing the common cultural heritage to the fore.' But exactly what this might consist of is at best vague and open to interpretation. It certainly suggests that there is not a prior unity or that diversity is an obstacle to a common Europeaness.

Unlike the previously discussed narrative of a common republican heritage, the idea of unity in diversity suggests a conception of the European heritage that is not defined in the terms of what might be termed 'Old Europe', namely a western European oriented definition of the European heritage. With the enlargement of the EU there is clearly a need for a wider definition of the European heritage to include the various forms of Europe, central, eastern, Balkan Europe. In addition to this, the notion of unity in diversity draws attention to the regional plurality of Europe below the national level. 


\section{Heritage as Trauma}

A different reading of the European heritage would take the unity and diversity theme to its limit and claim that the history of Europe has been inseparable from suffering. In this narrative it is more than a question of diversity; it is a matter of divisions. There are no common memories, only divided ones. For instance, any account of the Christian nature of European civilization must consider that this heritage divided as well as united Europe (see Delanty 1995). Christianity, like Europe itself, did not lead to a single church, but a diversity of religious traditions and different interpretations as to the meaning of secularism.

The concern with divisions in European history has recently been overshadowed by a stronger notion of trauma and collective memories shaped by trauma. The notion that the only adequate account of the European heritage is one based on the recognition of trauma has gained increased currency in recent years (see Giesen 2004). This narrative is reflected in accounts of the European heritage that highlight the holocaust, as in Christian Meier's (2005) From Athens to Auschwitz. He argues the problem of history is the centrality of Auschwitz, as the symbolic term to refer to the Holocaust as a whole. Auschwitz was the 'definitive end' of European history and must be taken into account in any assessment of the European heritage.

It is certainly the case that the past is becoming increasingly difficult to commemorate. Nation-states have generally succeeded in commemorating the past around some notion of liberation from an imperial power or wars against neighbouring countries. But for Europe as a whole, unlike most nation-states, there is no European people as such and consequently commemoration cannot be the remembrance of a specific people. For this reason, the idea of trauma suggests a more appropriate way for Europe to articulate its historical self-understanding. The proposal for the holocaust to be recognised as a European commemorative event is one such example of the entry of trauma into the very idea of the European heritage. This is not without some problems, since it raises the issue of which traumas should figure in such a reading of the European heritage. Since 1989 there has been a proliferation of discourses of victimhood, many of which are products of communist 
oppression in central and eastern Europe and cannot be easily reduced to a single or dominant position of victimhood. Indeed, in such discourses the line separating victim and perpetrator is a thin one.

\section{Cosmopolitan Heritage}

The received view is that European civilization is underpinned by fixed reference points, which are often associated with the Greek and Roman civilization, Christianity, the Renaissance and Enlightenment. Modernity, generally defined by reference to the Enlightenment, is held to be part of this heritage, which culminated in 'Modern Western Civilization.' An alternative view more, in keeping with current philosophical thinking and research in comparative historical sociology (see Arnason 2003), would suggest that the civilizational nature of Europe is far less tightly defined. By civilization, to follow Arnason, is meant a geopolitical constellation of societies that have been shaped by common cultural worlds - to which belong comprehensive interpretations of the world and broad cultural models - and material life. Civilizations are thus constellations of interacting societies in which power and culture are reflected in diverse ways. The notion of civilization, shed of its universalistic associations, is one way to thematise the interplay of unity in diversity.

Against this background, the cultural heritage, including the conventional reference points, can be interpreted in different ways. Before looking at this below, a few points of a general theoretical nature can be made with respect to Europe specifically. European civilization can be understood in plural terms in three related senses. First, it can be defined in a way that includes a multiplicity of civilizations within Europe; secondly it can be defined in way that includes a wider trans-continental dimension to inter-civilizational encounters; thirdly the specific civilizations under consideration should be seen as themselves highly plural. The upshot of this is a notion of a civilizational constellation, which is particularly pertinent to the European case, although by no means exclusively European. 
Under the first heading would be a notion of European civilization including a broader spectrum of civilizations than Greek and Roman civilization or a unitary notion of the Judeo-Christian civilization. An alternative and more inclusive civilizational approach would have to include the Byzantine tradition and its later revival in imperial Russia where it lent itself to Orthodox and Slavic cultural flows. Included too in a broad notion of the European civilizational constellation would be the Jewish diasporic civilization and the Islamic civilization, including its Turkish offshoot and modern European Islam. These different civilizations are not entirely separate but interact with each other. The Judaic civilization, for instance, is present in Islamic and Christian civilizations and the Byzantine civilization was related to both western and eastern traditions. Russian civilization includes both western and eastern civilizational currents. Modern Turkey is a combination of the Ottoman heritage and westernization.

Implied in this plural notion of the European civilizational constellation is a strong emphasis on civilizational encounters and in particular a relation to the wider EuroAsian context. This points to a hyphenated notion of civilizations as opposed to a singular notion, as in the terms Graeco-Roman civilization, the Judeo-Christian civilization, Byzantine-Russian civilization. The second aspect, the trans-continental dimension of inter-civilizational encounters, highlights the role the non-European world played in the making of Europe. This was a relation that itself took many forms, ranging from violent encounters to mutual learning. Europe variously borrowed, adapted, translated, the cultural, technological, scientific creations of other civilizations, in particular those of Asia. The reverse of course also happened. As a result of centuries of trade and later as a result of imperial ventures and colonization, the various European-Asian civilizations have become quite mixed. The important point is that any consideration of 'European Civilization' must include the nonEuropean dimension, a relation that has not one but many dimensions.

With respect to the various civilizations that make up the wider civilizational constellation, the internal pluralization of those civilizations must be emphasized. This internal pluralization can, in part, be explained by the wider inter-civilizational 
context, but it is more than this. Indeed, the very notion of a civilization suggests a diversity of social and cultural worlds that also bear some common patterns. I have previously referred to this as a 'post-western' conception of Europe (Delanty 2003, see also Delanty 2006). By this I mean a reading of European history that emphasizes internal pluralisation and interaction of different civilizational streams. It is postwestern, too, in the more specific sense that it invokes a notion of Europe that is less defined by reference to the West. This can be understood in two senses. Firstly, a notion of the European heritage that stresses the diversity of historical traditions that make up European history, and, secondly, a more European conception of Europe as European as opposed to Western. The notion of a post-western Europe may also be understood as cosmopolitan in order to highlight moments of openness and dialogue.

In different ways, this cosmopolitan approach is reflected in recent approaches to Europe, illustrated in works by Ulrich Beck (see Beck and Grande 2007), Etienne Balibar (2003) and Delanty and Rumford 2005). But it is also evident in recent historiographical scholarship, in particular with respect to new interpretations of the Renaissance (Brotton 2002, Brotton and Jardine 2000). In my view, this remains the most promising avenue for further reflection on the meaning of the European heritage. It is especially pertinent in the context of post1989 developments in Europe, for these undermine the assumptions of the older grand narratives and place greater emphasis on a unity in diversity and where the unity consists on multiple points of interaction rather than a progressive unfolding of a master narrative.

A critical cosmopolitan approach (see Delanty 2009) with respect to cultural phenomena, in brief, concerns a methodological emphasis on (1) the identification of openness to the world, (2) self-transformation in light of the encounter with the Other (3) the exploration of otherness within the self (4) critical responses to globality and (5) critical spaces between globality and locality. The significance of this for the analysis of European identity is that it provides a framework in which culture and identity can be examined in ways that do not reduce it to political identity or to collective identity, whether of institutions or culturally defined groups. It is here that 
the notion of a cultural model is particularly relevant. From the perspective of critical cosmopolitanism the task is to assess processes of self-transformation in which new cultural models take shape and where spaces of discourse open up, leading to a socio-cognitive change. A critical cosmopolitan theory proceeds on the assumption that the cultural models of society contain learning potential in terms of moral and political normative criteria.

\section{Conclusion}

In this paper I have sought to explore some of the considerations that are at stake in the debate on the European heritage. My argument is that the period since 1989 has been marked by a break-up of the grand narratives of the past. New narratives are emerging in the vastly growing discursive space of Europe. Looking at four major narratives, it can be concluded that contrary to the claims made by many critics, there is in fact no underlying European self or constitutive subject. To claim otherwise is to ignore some of the most important debates and developments in European thought over the past few decades. It is also not possible to claim that the European heritage has been always defined by reference to an external other, since much of the concern with otherness has been the European past itself. In sum, there is neither a clearly defined self nor other and much of the European heritage has been the endless reinterpretation of its own past. The notion that there is a past that can be recovered and made meaningful for the present has been seriously undermined by philosophical and historiographical scholarship. Yet, this does not mean the past can be of no service to the present. But rather than providing the present with a comfortable illusion of a unity that transcends its divisions, new and emerging narratives of the European heritage offer interpretations that are more in tune with the changing nature of European self-understanding in an increasingly post-European age. 


\section{References}

Antonsich, M. 2008 'Europe between "National” and "Postnational” Views' European Journal of Social Theory 11 (4): 505-22

Arnason, J. 2003 Civilizations in Dispute: Historical Questions and Theoretical Traditions. Leiden: Brill.

Arnason, J. 2006 'Contested Divergence: Rethinking the "Rise of the West" ', in Delanty, G. Europe and Asia Beyond East and West. London: Routledge.

Balibar, E. 2003 We are the European: Reflections of Transnational Politics. Princeton: Princeton University Press.

Beck, U. And Grande, E. 2007. Cosmopolitan Europe. Cambridge: Polity Press.

Brague, R. 2002 Eccentric Culture: A Theory of Western Civilization. South Bend, Ind.: St. Augustine's Press.

Brotton, J. 2002 The Renaissance Bazaar: From the Silk Road to Michelangelo. Oxford: Oxford University Press.

Brugmans, H. 1966 L'ideé europeéne, 1918-1965. Bruges: De Tempel.

Brugmans, H. (ed.) 1987 Europe: Réve-Aventure-Réalité. Brussels: Elsevier.

Checkel, J. and Katzenstein, P. eds 2009 European Identity. Cambridge: Cambridge University Press.

Davies, N. (1996) Europe - A History. Oxford: Oxford University Press.

De Rougemont, D. 1965 The Meaning of Europe. London: Sidgwick \& Jackson.

De Rougemont, D. 1966 The Idea of Europe. London: Macmillan.

Delanty, G. 1995 Inventing Europe: Idea, Identity, Reality, London: Macmillan

Delanty, G. 2003. 'The Making of a Post-Western Europe: A Civilizational Analysis', Thesis Eleven, 72: 8-24.

Delanty, G. (ed.) 2006 Europe and Asia Beyond East and West. London: Routledge.

Delanty, G. and Rumford, C. (2005) Rethinking Europe: Social Theory and the Implications of Europeanization London: Routledge.

Derrida, J. 1994 The Other Heading: Reflections on Today's Europe.

Bloomington: Indiana University Press.

Eder, K. 2009. 'A theory of collective identity: Making sense of the debate on a "European identity" ' European Journal of Social Theory 12 (4): 427-47.

Duroselle, J.-B. 1990 Europe - A History of its Peoples. London: Viking.

Giesen, B. 2004 Triumph and Trauma. Westview: Boulder. 
Jardine, L. and Brotton, J. (2000) Global Interests: Renaissance Art between East and West. London: Reaktion Books.

Goody, J. (2004) Islam in Europe. Cambridge: Polity Press.

Jaspers, K. 1947 Vom Europäischen Geist. Munich: Piper.

Joas, H. And Wiegandt, K. 9eds) 2007 Europe's Cultural Values. Liverpool: Liverpool University Press.

Habermas, J. 2001 'Why Europe Needs a Constitution'. New Left Review. 11. Sept/Oct.

Kantner, C. 2006 'Collective Identity as Shared Ethical Self-Understanding: The Case of an Emerging European Identity' European Journal of Social Theory 9 (4): 501-23.

Meier, C. 2005 From Athens to Auschwitz: The Uses of History. Cambridge, MA.: Harvard University Press.

Melucci, A. (1996) Challenging Codes: Collective Action in the Information Age. Cambridge: Cambridge University Press.

Pocock, J. G. A. 1997 'Deconstructing Europe'. In: The Question of Europe. P. Gowan and P. Anderson (eds) London: Verso.

Pocock, J. G. A. 2002 'Some Europes in their History'. In: The Idea of Europe: From Antiquity to the European Union. A. Pagden (ed.). Cambridge: Cambridge University Press.

Sassatelli, M. 2007. Becoming Europeans: Cultural Identity and Cultural Policy. London: Palgrave.

Strydom, P. 2006 'Contemporary European Cognitive Social Theory' in Delanty, G. (ed.) Handbook of Contemporary European Social Theory. London: Routledge.

Touraine, A. 1977 The Self-Production of Society. Chicago: University of Chicago Press.

Van Gelderen, M. and Skinner, Q. (eds) 2002 Republicanism: A Shared European Heritage. Vols 1 and 2. Cambridge: Cambridge University Press.

Wagner, P. 2009 Modernity as Experience and Interpretation: A New Sociology of Modernity Polity Press. 


\section{Recent LEQS papers}

Outhwaite, William. 'Europe at 21: Transitions and Transformations since 1989'. LEQS Paper No. 18, January 2010 I

Lavdas, Kostas A..'Normative Evolution in Europe: Small States and Republican Peace'. LEQS Paper No. 17, January 2010

Schelkle, Waltraud. 'Good governance in crisis or a good crisis for governance? A comparison of the EU and the US'. LEQS Paper No. 16, December 2009

Keating, Michael. 'Second Round Reform. Devolution and constitutional reform in the United Kingdom, Spain and Italy'. LEQS Paper No. 15, December 2009

Hyman, Richard. 'Trade Unions and 'Europe': Are the Members out of Step?'. LEQS Paper No. 14, November 2009

Dani, Marco. 'Economic and social conflicts, integration and constitutionalism in contemporary Europe'. LEQS Paper No. 13, November 2009

Rodríguez-Pose, Andrés \& Krøijer, Anne. 'Fiscal Decentralization and Economic Growth in Central and Eastern Europe'. LEQS Paper No. 12, October 2009

Cheshire, Paul C. \& Magrini, Stefano. 'Urban Growth Drivers and Spatial Inequalities: Europe - a Case with Geographically Sticky People. LEQS Paper No. 11, October 2009

McCrea, Ronan. 'The Recognition of Religion within the Constitutional and Political Order of the European Union'. LEQS Paper No. 10, September 2009

Bertola, Guiseppe \& Mola, Lorenza. 'Services Provision and Temporary Mobility: Freedoms and Regulation in the EU' LEQS Paper No. 9, September 2009

Walker, Neil. 'Multilevel Constitutionalism: Looking Beyond the German Debate'. LEQS Paper No. 8, June 2009

Frankel, Jeffrey. 'The Estimated Trade Effects of the Euro: Why Are They Below Those From Historical Monetary Unions Among Smaller Countries?'. LEQS Paper No. 7, June 2009

Colomer, Josep M.. 'On Building the American and the European Empires'. LEQS Paper No. 6, June 2009

Boeri, Tito. 'Immigration to the Land of Redistribution'. LEQS Paper No. 5, June 2009

Jones, Erik. 'They Have No Idea... Decision-making and Policy Change in the Global Financial Crisis'. LEQS Paper No. 4, May 2009

Frey, Bruno. 'A New Concept of European Federalism'. LEQS Paper No. 3, May 2009

Chalmers, Damian. 'Gauging the Cumbersomeness of EU Law'. LEQS Paper No. 2, May 2009

Bellamy, Richard. 'The Liberty of the Post-Moderns? Market and Civic Freedom within the EU’. LEQS Paper No. 1, May 2009 


\section{LEQS}

European Institute

London School of Economics

Houghton Street

WC2A 2AE London

Email: euroinst.LEQS@lse.ac.uk

http://www2.lse.ac.uk/europeanInstitute/LEQS/Home.aspx 